\title{
The Revelation of the Potential Culture and Entrepreneurship: An Effort to Minimize the Unemployed Graduates of Salaf Islamic Boarding Schools in Tapal Kuda Areas, East Java, Indonesia
}

\author{
Akhmad Haryono \\ Universitas Jember \\ email: aharyono.sastra@unej.ac.id \\ Lutfi Arifianto \\ Universitas Jember \\ email: lutfipls.fkip@unej.ac.id \\ Supardi \\ Universitas Jember \\ email: supardi@unej.ac.id \\ Ika Barokah Suryaningtiyas \\ Universitas Jember \\ email: ikabarokah@gmail.com \\ Evita Soliha Hani \\ Universitas Jember \\ email: ita_hani.faperta@unej.ac.id \\ Mohammad Iqbal \\ Universitas Jember \\ email: iqbal.fkip@unej.ac.id
}

\begin{abstract}
Islamic boarding schools are an alternative educational institution for people in East Java Tapal Kuda areas. Therefore, Islamic boarding schools have a very large contribution in the development of human resources. This study aims at finding out the potential culture and entrepreneurship and the factors that can affect the unemployed graduates of the Salaf Islamic Boarding School. The
\end{abstract}


qualitative approach method is used to achieve the research objectives. The data were obtained through participant observation and interviews with recording techniques and notes. As supporting data, quantitative data were also explored through questionnaires. The data obtained through interviews were then interpreted qualitatively, while quantitative data were in percentage in the form of tables and the results were then described. This study result found out that entrepreneurial behavior of graduates of the Salaf Islamic Boarding Schools can be categorized as very low. Some factors causing the high-unemployed graduates of Salaf Islamic Boarding Schools are factor of culture focusing only on religious books, factor of student's very low education, factor of Islamic boarding schools curriculum that is not oriented on entrepreneurship, factor of parents' low education, and factor of parent's economy. Among these factors, Salaf Islamic Boarding School curriculum factor is the most dominant because of no curriculum that can provide entrepreneurial skills to students (santri). Through changes in entrepreneurial oriented curriculum it is expected to reduce the unemployed graduates of Islamic boarding schools.

[Pesantren merupakan lembaga pendidikan alternatif masyarakat di daerah Tapal Kuda Jawa Timur. Oleh karena itu, pondok pesantren memiliki kontribusi yang sangat besar dalam pembangunan sumber daya manusia. Tujuan penelitian ini untuk mengetahui potensi budaya dan kewirausahaan serta faktor-faktor yang dapat berpengaruh terhadap pengangguran lulusan Pondok Pesantren Salaf. Metode pendekatan kualitatif digunakan untuk mencapai tujuan penelitian. Data diperoleh melalui observasi partisipasi dan wawancara dengan teknik rekam dan catat. Sebagai data pendukung juga digali data kuantitatif melalui penyebaran kuesioner. Data yang diperoleh melalui wawancara selanjutnya diinterpretasi secara kualitatif, sedangkan data kuantitatif dipersentase dalam bentuk tabel dan selanjutnya hasilnya dideskripsikan. Penelitian ini menghasilkan temuan bahwa Perilaku kewirausahaan lulusan Pondok Pesantren Salaf dapat dikategorikan sangat rendah. Beberapa faktor yang menyebabkan banyaknya pengangguran lulusan Pondok Pesantren Salaf yaitu Faktor budaya yang hanya memfokuskan studi pada kitab-kitab keagamaan, faktor pendidikan siswa tergolong sangat rendah, faktor kurikulum pondok pesantren yang belum berorientasi pada kewirausahaan, faktor pendidikan orang tua yang tergolong rendah, faktor ekonomi orang tua. Diantara faktor-faktor tersebut yaitu faktor kurikulum Pondok Pesantren Salaf yang paling dominan, karena belum adanya kurikulum yang dapat memberikan bekal keterampilan kewirausahaan kepada murid (santri).Melalui perubahan kurikulum yang berorientasi 


\section{kewirausahaan diharapkan dapat mengurangi pengangguran lulusan} pondok pesantren.]

Keywords: culture; entrepreneurship; Islamic boarding school

\section{Introduction}

In Indonesia, especially in Tapal Kuda areas of East Java there are generally two types of Islamic Boarding School, namely Salaf Islamic Boarding School and Khalaf Islamic Boarding School. The Salaf Islamic Boarding School is a type of boarding school that focuses its study only on religious sciences (diniyah) which are still traditionally managed. The Khalaf Islamic boarding school is a blend of religious knowledge and general science and is managed with an advanced system, even equipped with public schools from elementary to tertiary levels.

In relation to nation-building, especially those related to the development of human resources, we cannot leave the Islamic Boarding School as an alternative educational institution that lives in rural communities. The Islamic Boarding School is a place of alternative education for rural communities with a lower-income of economic background. Therefore, the Islamic Boarding Schools, especially in East Java have a huge contribution to the development of human resources. The Islamic Boarding School will have a greater contribution to creating human resources, if the campus is equipped with skills that support entrepreneurship.

The successful development in Indonesia will be increasingly visible if there are many mushrooming entrepreneurs who can create jobs due to the the government's very limited ability to provide employment. Therefore, entrepreneurship is a development potential, both in the number and in the quality of the entrepreneurship itself. There are two ways of entrepreneurial service towards nation building that entrepreneurs can: (1) overcome the difficulties of employment, and simultaneously increase people's income; and (2) increase national resilience and reduce dependence on others, even on other nations. ${ }^{1}$ The success of the development achieved by Japan was apparently

1 B. Alma, Entrepreneurship: For Students and the Public (Bandung: Alfabeta, 2008). 
sponsored by entrepreneurs who have amounted to $2 \%$ in the middle level, as small entrepreneurs as $20 \%$ of the total population. This is the key to the success of Japan's development. ${ }^{2}$

The Salaf Islamic Boarding School have different teaching patterns, referring to the pattern of Salaf Islamic Boarding School teaching where caregivers (Kyai) gained the knowledge before. However, none of the Salaf Islamic Boarding Schools has an entrepreneurial curriculum. Meanwhile, the graduates of the Salaf Islamic Boarding School have increased the number of unemployed people, which can lead to many conflicts and the difficulty of economic growth in rural communities. There is a number of factors that are assumed to cause the unemployed graduates of many Salaf Islamic Boarding Schools. Most of them are very low levels of santri education with elementary school graduates, and even many of them do not graduate from elementary school; the family's economic level is low, so they cannot provide opportunities for business capital to their children who are graduated from the Islamic Boarding School; the absence of entrepreneurial encouragement and debriefing during their study at the Islamic Boarding School, even though they were mostly very long in the Islamic Boarding School, ranging in age from children to teenagers before getting to marriage.

The uniqueness of the Islamic Boarding School community makes many experts interested in researching and writing challenges to Islamic boarding schools. Sujoko Prasodjo et al. (1974) examined the Darul Falah Islamic Boarding School and eight Islamic boarding schools in Bogor, with topics of growth history, value systems, curriculum and various opinions about Islamic Boarding School and their potential. ${ }^{3}$ Mastuhu (1994) has examined the dynamics and value of the education system in six Islamic boarding schools in East Java. ${ }^{4}$ Likewise, Nasir (2003) examined the title "Islamic Education in Islamic Boarding Schools: Study of Types of Islamic Boarding

\footnotetext{
${ }^{2}$ Ibid.

${ }^{3}$ Dawam Rahardjo (ed.), Pesantren dan Pembaharuan (Jakarta: LP3ES, 1988).

${ }^{4}$ Mastuhu, Dinamika Sistem Pendidikan Pesantren: Suatu Kajian Tentang Unsur Dan Nilai Sistem Pendidikan Pesantren (Jakarta: INIS., 1994).
} 
Schools". Haryono (2006) in his research discussed about "Communication Patterns in Islamic Boarding Schools in Jember". 6 Maunah (2009), in her research entitled "Islamic Boarding Schools in the Perspective of Social Change", found that boarding schools were an agent of change who lived in the midst of society. ${ }^{7}$

Haryanto (2011) conducted a research entitled "Students' Perception of Kiai's Leadership Behavior in Islamic Boarding Schools: Symbolic Interactionism Study at Sidogiri-Pasuruan Islamic Boarding School. It found that the leadership behavior of religio-kiai was transformative; the variant model of kiai's interaction with santri and the manifested balance of the functions and meanings of the santri's life can illustrate that the santri were given opportunities to develop the quality of santri resources. The interrelation between propositions above offers a concept that the religio-transformative kiai's leadership behavior, the religious system actualization, the balance of functions and the meaning of the santri's life are the determinations of the birth of variants of the interaction model; physical interaction, interaction of mindset, and interaction of spirits in the social life of the boarding school community. The three variants of the interaction model are almu'amalah al-jismiyah (physical interaction), al-mu'amalah alfikriyah (intellectual interaction), and al-mu'amalah al-rûhiyah (spiritual interaction). ${ }^{8}$

Sari (2017), in her research entitled "The Role of Learning Management on Islamic Boarding School (Pesantren) in Improvement of Their Students Religious Tolerance in West Java - Indonesia", found that increasing students' religious tolerance is done through learning management by applying various learning theories and comprehensively through the methods of sorogan, bandongan, fathul kutub, muhawarah, mudzakaroh and memorization based on ukhrawi.

\footnotetext{
${ }^{5}$ A.S. Nasir, "Pendidikan Islam di Pesantren (Studi tentang Tipe Pesantren)," Jurnal Pancaran Pendidikan 16, no. 4 (2003): 96-106.

${ }^{6}$ A. Haryono, "Pola Komunikasi di Pesantren Salaf 'A' Jember (Kajian Sosiolinguistic)" (Thesis, Universitas Negeri Surabaya, 2006).

${ }^{7}$ B. Maunah, "Pesantren in the Perspective Social Change," Jurnal Ushuluddin 30, no. 2 (2009): 251-282.

${ }^{8}$ S. Haryanto, "Persepsi santri terhadap perilaku Kepemimpinan Kiai di Pondok Pesantren: Studi Interaksionisme Simbolik di Pondok Pesantren Sidogiri-Pasuruan" (Doctoral Thesis, Universitas Islam Negeri Maulana Malik Ibrahim, 2011).
} 
While the effectiveness of classroom management is done by making students as subjects so as to motivate students in their cognitive, affective and psychomotor development. Students who have tolerance are expected to uphold an attitude of respect, appreciation, recognition and ease in preaching in public. ${ }^{9}$

Himmah (2017) in her research entitled "Curriculum Development of The Arabic Language of Mu'adalah Participants (Case Study in Al-Kautsar Genteng Banyuwangi Islamic Boarding School)" resulted in findings that based on this study, it was found that Arabic curriculum planning at the boarding school places the book, which is provided the material for the study using the book the classic form of Jurumiyah and Imrity for the Nahwu lessons. ${ }^{10}$

Raihani (2017) in her research entitled "Exploring Islamic School Leadership in a Challenging Southern Thailand Context" suggests that the principals, in their planning activities, growing niche to think Strategically for the benefit of reviews their schools, Reviews their students, and the community at large, that is willing to compromise with the government so as not to contradict their religious beliefs and principals ice, and that they have a strong vision for school improvement. ${ }^{11}$

Halim (2017) whose research is based on "The Role of Islamic Boarding Schools in Discourse and Empowerment of Civil Society" explores that the existence of Islamic boarding schools as the oldest and largest Islamic educational institution in Indonesia plays a role as one of civil society elements which, in turn, can contribute

\footnotetext{
9 M.M.E. Sari, "The Role of Learning Management of Islamic Boarding School (Pesantren) in Improvement of Their Students Religious Tolerance in West Java Indonesia," International Journal of Innovation and Applied Studies 19, no.1 (2017): 24-32.

10 R. H. Himmah, M. A. Amrulloh, "Pengembangan Kurikulum Bahasa Arab Pesantren Mu'adalah (Studi Kasus di Pondok Pesantren Al-Kausar Genteng Banyuwangi)," Al Bayan: Jurnal Jurusan Pendidikan Bahasa Arab 9, no. 2 (2017): 75-89.

11 Raihani, "Exploring Islamic School Leadership in a Challenging Southern Thailand Context," Studia Islamika: Indonesian Journal for Islamic Studies 24, no. 2 (2017): 271-294.
} 
significantly in efforts to transform and empower civil society as part of the ongoing process of democratic consolidation in Indonesia. ${ }^{12}$

Hamid (2017) in his book entitled "Character Education Based on Islamic Boarding Schools: Students (santri) in the era of IT and Cyber Culture" concluded that character education which has a base in Islamic boarding schools has a very important and strategic role in the history of national education. In this era, the Indonesian nation increased its commitment to make education a means to realize the nation of Indonesia as a nation that is religious-character and highly competitive through IT utilization. ${ }^{13}$

Wardi (2017), in his research entitled "Development of entrepreneurship based on experiential learning in Al-Amien Islamic boarding schools in Prenduan Sumenep and Darul Ulum Banyuanyar Pamekasan", found that the form of entrepreneurial development Learning experiences (learning based on direct experience) are: industrial work practices (prakerin) rihlah iqtishadiyah, reward baketram, ngabuleh/khaddam-clerical (family assistants), "control the corner", inspire dual school behavior acting as an entrepreneur and pesantren leader, the scholars slogan "hard work, smart work, and sincere work". ${ }^{14}$

Kompri (2018) in Islamic Boarding School Management \& Leadership emphasizes management and leadership in Islamic boarding schools. Isbahi (2018) in his research entitled "The Culture of Pakewuh Santri to the Kyai: The Relevance of the Culture of Islamic Boarding School Education to the Challenges of the Islamic World in the Era of Globalization" resulted in the leadership in the Islamic culture (kyai) found in the still traditional and leadership in the transitional community - especially in modern society and metropolis society - have experienced a crisis of legitimacy, irrelevant sense in the era of globalization, and degradative changes, due to various dynamics

12 W. Halim, "Peran Pesantren dalam Wacana dan Pemberdayaan Masyarakat Madani," Akademika 22, no. 2 (2017): 191-218.

${ }^{13}$ A. Hamid, Pendidikan Karakter Berbasis Pesantren: Pelajar dan Santri dalam era IT dan Cyber Culture (Surabaya: Imtiyas, 2017).

${ }^{14} \mathrm{M}$. Wardi, "Pengembangan entrepreneurship berbasis experiential learning di pesantren Al-Amien Prenduan Sumenep dan Darul Ulum Banyuanyar Pamekasan," (Ph.D. Thesis, UIN Sunan Ampel Surabaya, 2017). 
and changes, both internal pesantren and external dynamics of the muslim community. ${ }^{15}$

Those previous studies more emphasize on the leadership of kiai and the transformation of education and entrepreneurship in general in several Islamic boarding schools. None of them has discussed the topic of entrepreneurship curriculum in salaf Islamic boarding schools, especially in Tapal Kuda regions. For this reason, this study specifically discusses the importance of the salaf Islamic boarding school curriculum focused on the entrepreneurship in Tapal Kuda areas, so that the students in the Salaf Islamic Boarding Schools are not only focused on studying religious sciences, but on the sidelines demanding religious sciences and traditional Islamic Boarding School activities that they can equip themselves with skills that can inspire entrepreneurship in accordance with their potential in the area of Islamic boarding schools.

Thus, this article is expected to provide a new perspective for the world of Islamic boarding schools, especially for the graduates of the Salaf Islamic Boarding School, who have tended to be a burden to the community, because the graduates mostly increase the number of unemployed. In addition, this article can at the same time reveal in depth the factors that can lead to a large number of unemployed alumni of the Salaf Islamic Boarding School, so it is easy to solve the problems related to the Salaf Islamic Boarding School community. Based on the above background, the questions are formulated as the followings: a) How far is the importance of the entrepreneurship curriculum in Islamic boarding schools?; b) What factors can trigger the proliferation of the Salaf Islamic Boarding School graduates?

\section{Methods}

This study belongs to a qualitative reasearch because it uses an interpretative, naturalistic/natural (not designed or prior treatment) approach, intepretes the meaning of the data, based on empirical material, and describes routine and problematic events. With this approach, according to Bogdan and Taylor, a qualitative research is

\footnotetext{
${ }^{15}$ Kompri, Manajemen \& Kepemimpinan Pondok Pesantren (Jakarta: Prenadamedia Group Divisi Kencana, 2018).
} 
that producing descriptive data in the form of written or oral data from people and observable behavior. However, this research is also supported by quantitative data through questionnaires to respondents. ${ }^{16} 17$

The research location is in Tapal Kuda areas. The data were obtained through participant observation and interviews with recording techniques. Recording was done to anticipate the limitations of researchers in recording the interview process. The recorded data were then transcribed into phonologically written data according to the original. As supporting data, quantitative data were also explored through the distribution of questionnaires (questionnaires) to respondents. The data obtained through interviews were interpreted qualitatively, while quantitative data were in percentage in the form of tables and finally the results were described to answer the research problems.

\section{Results}

\section{Entrepreneurship Behavior of the Salaf Islamic Boarding School Graduates}

Speaking about the behavior of Islamic Boarding School graduates, of course it is inseparable from the process of forming behavior, talents and interests during the education process in Salaf Islamic Boarding School in both formal and informal education. The formation process is of course also inseparable from the teaching reference that is followed, including the curriculum/learning reference which is a reference in the learning process in boarding schools. Entrepreneurial behavior of Salaf Islamic Boarding School graduates can be seen from the type of work occupied by graduates, the types of skills possessed by graduates, entrepreneurial experience while in boarding schools, and the attractiveness of Salaf Islamic Boarding School graduates towards entrepreneurship.

\footnotetext{
${ }^{16}$ R. Bogdan and I.S. Taylor, Introduction to Qualitative Research to the Social Sciences (New York: John \& Sons, Inc., 1975).

17 A. Haryono, Etnografi Komunikasi: Konsep, Teori, dan Contoh Penelitian Pola Komunikasi (Jember: UPT Publishing University of Jember, 2015).
} 


\section{Revealing the Job Types of Salaf Islamic Boarding School Graduates}

The types of work occupied by Salaf Islamic Boarding School graduates are mostly farmers and traders, only a small proportion of which succeed in becoming Koran teachers, religious teachers and clerics. Eventhough the Salaf Islamic Boarding School only focuses its study on the kitab kuning (yellow book: religious books). This shows that the pattern of teaching in the Salaf Islamic Boarding School is only oriented towards creating the students to master the religious sciences alone. This means that the learning program at the Islamic Boarding School only aims to create the students into a Kyai, Ustadz, or teacher of the Koran.

However, conditions in the field show that the graduates of the Salaf Islamic Boarding School who received the title are very small. While the need for life in society is increasingly complex. According to KH. Muchsin, a cleric who had studied in a salaf Islamic boarding school, stated that: "being a Kyai or an ustadz who raises is a society or there are derivatives of parents or in-laws. Therefore when a human child comes out of the womb of a Nyai (kyai's wife), he immediately bears the title of lora (gus). And those who raised the title were also people. Another source also said that the graduates of the schools of the Salaf are very few who become kiai, because not all students possessed the talent to become a teacher of the Koran, a religious scholar, or scholars." (Interviews results, 08/08/2018)

The data indicates that boarding schools cannot appoint santri with the title of a kyai, but Islamic Boarding School can provide the knowledge needed to become a kyai. The teaching that has been given in the message is the study of the kitab kuning (religious books) which specifically provide provisions for students to have the opportunity to become a kyai. However, as said by the informant being a kyai is not easy, but requires special treatment from the santris themselves or indeed there are derivatives from both parents and in-laws. Based on quantitative data obtained in the field, presenting the students who received the title of Kiai is very low, it can be seen from the following data: 


\begin{tabular}{|l|l|c|c|}
\hline No & \multicolumn{1}{|c|}{ Occupation } & Number & Percentage \\
\hline 1. & Kiai, Ustadz, Master Ngaji & 9 & $9 \%$ \\
2. & Farmers & 28 & 28 \\
3. & Traders & 28 & 28 \\
4. & Other $\quad$ Total & 100 & $35 \%$ \\
\hline & \multicolumn{1}{|c|}{ Ton } \\
\hline
\end{tabular}

The quantitative data indicates that most of the graduates of the Salaf Islamic Boarding School have various professions, 35\% of which consist of laborers, drivers, farm workers, expatriates, etc. $28 \%$ of farmers and traders, and those who are kyai professors, religious teachers / clerics are only 9. This means that graduates of the Salaf Islamic Boarding School who are in accordance with the teaching program at the Islamic Boarding School namely the yellow book study are very low. Thus it can be said that the Islamic Boarding School graduates are more engaged in entrepreneurship, only a few have the title of kyai, because kyai is not a profession appointed by the Islamic boarding school, but is a community convention that gives that title to someone. However, the entrepreneurial profession that is owned by graduates of the Salaf Islamic Boarding School is not based on the abilities and skills related to the field of entrepreneurship.

\section{Types of Skills Owned to Support the Family Economy}

Graduates of the Salaf Islamic Boarding School mostly do not have adequate skills. The skills that a small portion of the Salaf Islamic Boarding School graduates have mostly come from talents owned by family and the surrounding environment where they were raised, and also some who have innate talent from birth. These skills include: carpentry, haircut, trading, farming etc. The limitations of the skills possessed, as a result of limited skills learning while in boarding schools, never even gained experience and learning skills. They only get the study of the kitab kuning scriptures. According to some santri graduates of the Salaf Islamic Boarding School stated that "we did not have the skills that could be used as provisions to get a decent job after returning to the community. While other Islamic Boarding School graduates say that they have the skills we bring from home. We get these skills from parents and relatives who have carpentry, driver, haircut skills etc." (Interview results, 08/08/2018) 
The data confirms that graduates of the Salaf Islamic Boarding School do not have the skills, when they graduate from the Islamic boarding school. They feel confused about the work they will pursue after studying in the Salaf Islamic boarding school. Thus, it can be said that the limitations of the skills they have can lead to difficulties in obtaining employment as well as creating employment. This also means that entrepreneurial behavior of Salaf Islamic Boarding School graduates is very low.

The low level of skills possessed by the graduates of the Salaf Islamic Boarding School can also be seen from the data from the distribution of the following questionnaire:

\begin{tabular}{|c|c|c|c|}
\hline No. & Skill & Number & Percentage \\
\hline 1. & Has & 25 & $25 \%$ \\
\hline 2. & No & 75 & $75 \%$ \\
\hline & Total & 100 & $100 \%$ \\
\hline
\end{tabular}

Based on these data only $25 \%$ of students have skills , and up to $75 \%$ who lack skills. Based on information from students who have the skills that the skills they have are skills adopted from skills that can be done by parents such as builders, carpenters, drivers, traders, and farm workers. The type of work according to their statement is not a promising skill to bring a more prosperous life after the santri to buy into the community. The data also indicates that graduates of the Salaf Islamic Boarding School are still far from forming entrepreneurial behavior that promises better santri life in society.

Commenting on the behavior of graduates of the salaf Islamic boarding school, KH Muchsin added that, now Islamic boarding schools are irrelevant only given religious learning, but must begin to be given the provision of learning that will be truly needed by the community and beneficial for their lives. This is in line with the Qur'anic verses which read "Allah will not change the fate of someone unless someone wants to change it themselves." (Interview results, 08/08/2018) 
The data show that the entrepreneurship education is important for the santri's future life in society. With entrepreneurial skills, of course, the graduates of the Salaf Islamic Boarding School are more likely to be involved in helping development in the community.

\section{Experience in the Field of Entrepreneurship}

Experience in the field of entrepreneurship is also one of the factors that can determine the formation of entrepreneurial behavior for everyone. Experience can be obtained by someone by looking at and observing people doing a job, helping other people to do a job, or trying to do something based on the theory that he had read or that he learned from literature and other people. Some Salaf Islamic Boarding School in deed employ students in the trade, agriculture and possibly fisheries sectors. However, not all santri get their turn to do this. Because the initial goal was not to give more provision to the santri, but it was indeed a business of kyai (caregivers Islamic boarding school). while in the Salaf Islamic Boarding School the santri are only required to learn to read the yellow books (religion).

According to the recognition of several santri graduates from the salaf Islamic Boarding School, during their time at the Islamic Boarding School. They rarely did skills work which could be used as supplies after we returned to the community. In boarding schools as long as we are diligent in learning the yellow books are good, not required to work. Because we came to the Islamic Boarding School it was only hoped that parents would be smart in the field of religion. (Interview results, 08/08/2018)

The data indicate that in the Salaf Islamic Boarding School it is only monotonous to study religious knowledge which in the Islamic Boarding School is known as the kitab kuning. They are generally not provided time to do other activities including learning skills. This means that during the Islamic Boarding School the santri find it difficult to obtain experiences that can be used as provisions after returning to the community. This is in accordance with the expectations of parents, so smart Syar'i knowledge. The data is supported by data from the results of a questionnaire distributed to graduates of the schools of the Salaf as follows: 


No. Experience Amount Percentage
Entrepreneurship

\begin{tabular}{|c|c|}
\hline 1. Have & 28 \\
\hline Have not & 72 \\
\hline
\end{tabular}

\begin{tabular}{rrr}
\hline Total & 100 & $100 \%$ \\
\hline
\end{tabular}

The data show $72 \%$ do not have entrepreneurial experience and only $28 \%$ has entrepreneurial experience. Based on information from graduates of the Salaf Islamic Boarding School who have successfully confirmed that $28 \%$ of graduates of Islamic Boarding Schools have gained experience in the community from parents, friends, close relatives and neighbors. This also means that the percentage of graduates of the Salaf Islamic Boarding School has very little entrepreneurial experience in the Islamic Boarding School. Thus it can be said that the entrepreneurial behavior of Salaf Islamic Boarding School graduates after returning to the community is very low in entrepreneurial behavior.

\section{Santri's Interest in Entrepreneurship}

Everybody wants a life that is prosperous both outer and inner, including graduates of the Salaf Islamic Boarding School. A good and successful life must be accompanied by efforts and hard work. As mentioned above that "Allah will not change one's destiny unless he himself tries to change it". Most of the Salaf Islamic Boarding School graduates have an interest in doing business or the language that is often used is trading. However, they find it difficult to start the work because they do not have sufficient skills and experience as mentioned above.

Based on information from several graduates of the Salaf Islamic Boarding School, they stated that, "We are graduates of the Salaf Islamic Boarding School who are actually interested in doing business in the trade sector, considering that the work is an ordinary work carried out by the Prophet. So that when done 
get the sunnah and the reward is also reward from Allah SWT. (Interview results, 09/08/2018)

The data confirm that the graduates of the Salaf Islamic Boarding School are interested in doing business or trading because the work is a work done by the Prophet. by following what was done by the apostle, in addition to getting welfare and blessing the santri also hoped that what he did was worth the worship of the sunnah, which when done got rewards from Allah Almighty. This means that in fact there are quite a large number of graduates of the Salaf Islamic Boarding School. However, they do not have the carrying capacity of skills, management, and entrepreneurial experience.

The data on the attractiveness of entrepreneurship, especially in the field of trade and utilization of skills is also strengthened by the quantitative data were successfully captured through the following questionnaire:

\begin{tabular}{llcc}
\hline No. & Entrepreneur Desired & Amount & Percentage \\
\hline 1. & Interested (traders, skills) & 91 & $91 \%$ \\
2. & Not interested & 9 & $9 \%$ \\
\hline & $\quad$ Amount of & 100 & $100 \%$ \\
\hline
\end{tabular}

The data show $91 \%$ of respondents said they were interested in entrepreneurship and most of the $91 \%$ said they were interested in business / trade and skills, only 9\% said they were not interested in entrepreneurship. This means that most graduates of the Salaf Islamic Boarding School have an interest in entrepreneurship. Thus it can be said that it is very important in Islamic boarding schools to present entrepreneurial learning. Every learning process is of course important to prepare a syllabus that refers to the curriculum. Therefore, in the Salaf Islamic Boarding School an entrepreneurial oriented curriculum is needed.

\section{Factors Causing the High Unemployment of Salaf Islamic Boarding School Graduates}

Unemployment is a problem that is often found in many countries, including in Indonesia, both formally and informally, 
private or public graduates. Likewise, graduates of the Salaf Islamic Boarding School who incidentally do not have adequate education in terms of both general education and skills education related to skills and professions. To overcome this problem the government is now advocating for entering entrepreneurship curricula in universities. This is so that college graduates are not only able to find work in government and private institutions, but university graduates are expected to be able to create work with the knowledge and skills they have. To find out the unemployment rate of Salaf Islamic Boarding School graduates, it can be seen from the following discussion:

\section{Financial Factors and Skills}

The main obstacle of Salaf Islamic Boarding School graduates to entrepreneurship is the low level of their economy, making it difficult to have business capital. In addition, as the explanation above the low level of education and the lack of expertise and experience possessed by Salaf Islamic Boarding School graduates have caused a high rate of unemployment for graduates of the salaf Islamic boarding school.

Based on the information that the santri had succeeded in stating how we can try to have capital we don't have, even though there is also capital to be made. We don't have sufficient skills. But if there is enough capital can trade . (Interview results, 11/08/2018)

The data indicate that there are two important things that can cause high rates of unemployment in Islamic Boarding School, namely the limited capital and limited skills and entrepreneurial experience they have. This shows that graduates of the Salaf Islamic Boarding School will find it difficult to find and create work as a provision to fulfill their daily needs. As supporting data, supporting data has been obtained as follows:

\begin{tabular}{lll}
\hline No. Constraints & Amount & Percentage \\
\hline
\end{tabular}




\begin{tabular}{llcc}
\hline 1. & No capital & 85 & $85 \%$ \\
2. & No entrepreneurship skills / & 15 & $15 \%$ \\
& experience & & \\
3. & Not responding & 100 & $100 \%$ \\
\hline & Total
\end{tabular}

The results of the questionnaire show $85 \%$ of their statements do not have capital, $85 \%$ also feel they do not have adequate entrepreneurial skills and experience and $15 \%$ do not respond. The data also means that graduates of the Salaf Islamic Boarding School can largely increase unemployment in the community. This also means that graduates of the Salaf Islamic Boarding School have very low entrepreneurial behavior.

\section{Santri Education Factors}

The level of education is one of the determinants of success or failure in obtaining or creating work in society, because with adequate education one can think and act more broadly in the community. For example two people who both work as chicken sellers, one elementary school graduate and one high school graduate. The fact proves that high school graduates are more successful and develop their businesses faster. Judging from the level of education graduates of the Salaf Islamic Boarding School are mostly elementary school graduates, few have graduated from junior high school, and very few have graduated from high school.

Based on the results of questionnaires distributed to the 100 respondents obtained the following data:

\begin{tabular}{llcc}
\hline No. & Level of Education & Total & Percentage \\
\hline 1. & Elementary & 73 & $73 \%$ \\
2. & Junior high school & 21 & $21 \%$ \\
3. & High school & 6 & $6 \%$ \\
\hline & Total & 100 & $100 \%$ \\
\hline
\end{tabular}

The data show $73 \%$ of primary school graduates, $21 \%$ junior high school graduates, and only $6 \%$ are high school graduates. The 
data indicate that graduates of the Salaf Islamic Boarding School are very low in human resources (HR). Thus, it results in their low creativity in finding and creating work. In other words, education is one of the factors causing the many unemployed graduates of the Salaf Islamic Boarding School.

\section{Teaching Model Factors in The Salaf Islamic Boarding Schools}

The Pattern of education in Salaf Islamic Boarding School only focuses on the study of the yellow books (books that are only religiously oriented). On the contrary there is no opportunity for santri to learn skills that can be the provision of the santri when they return to society.

Based on information from the santri graduates of the Salaf Islamic Boarding School, they stated that they had never had entrepreneurial experience and learning while in the Salaf Islamic boarding school. We only study kitab kuning everyday and other religious books. (Interview results, 11/08/2018)

These data indicate that graduates of the Salaf Islamic Boarding School have never received the provision of experience and learning skills that can be used as provisions to find work and create work. This means that the Salaf Islamic Boarding School graduates are very possible to increase the number of unemployed people. This also means that the pattern of teaching in the Salaf Islamic Boarding School which never presents learning with the nuances of entrepreneurship is one of the factors increasing unemployment of its graduates. The data is strengthened by the results of the questionnaire distributed to respondents as follows:

\begin{tabular}{llcc}
\hline No. & $\begin{array}{l}\text { Entrepreneurship } \\
\text { Education Learning }\end{array}$ & Number of & Percentages \\
\hline 1. & Never & 26 & $26 \%$ \\
2. & Never & (calligraphy, & $74 \%$ \\
& & agriculture) & \\
& & 74 & \\
\hline
\end{tabular}


Total

100

The Data show $74 \%$ of Islamic Boarding School graduates claim never got entrepreneurial learning, and only $26 \%$ of respondents had learned about calligraphy and agricultural management skills. Thus it can be said that graduates of the Salaf Islamic Boarding School have very little entrepreneurship learning. This also means that graduates of the Salaf Islamic Boarding School are very likely to become unemployed in society.

\section{Parent's Education Factors}

Low level of education of parents can also be a cause of the low interest of children in education. Because the low level of education of parents is also a cause of not respect for education, so it is less likely to be able to motivate children to be able to continue their education to a higher level. Based on the respondents' acknowledgment, we have never received support for schools to a higher level. Parents only recommend to stay that we can read the yellow book and later become kyai or ustadz. (Interview results, $12 / 08 / 2018$ )

The Information shows that parents never motivate their children to pursue higher education, so that they will return to their future communities for the better. Most parents want their children to become kyai, ustadz or teacher of the Koran. However, as explained above, the Islamic Boarding School who succeeded in holding the title were very low. This also indicates that the education of parents can also cause many unemployed graduates of the Salaf Islamic Boarding School. The education level of parents also can be seen in the following table:

\begin{tabular}{llrc}
\hline No. & Level of Education & Total & Percentage \\
\hline 1. & Elementary & 77 & $77 \%$ \\
2. & Junior high school & 6 & $6 \%$ \\
3. & Senior high school & - & - \\
4. & Dropout & 17 & $17 \%$ \\
\hline \multicolumn{2}{r}{ Total } & 100 & $100 \%$ \\
\hline
\end{tabular}


The data show $77 \%$ of people santri's parents/guardians have elementary education, only $6 \%$ graduated from junior high school and $17 \%$ do not go to school/dropout. This shows that the education level of santri's guardians is still very low. This can also be the cause of the low motivation of parents to continue their education of their children to higher levels of schooling and based on entrepreneurial skills. Thus it can also be said that parental education can be a factor in the many unemployed graduates of the Salaf Islamic Boarding School.

\section{Motivation Factor}

Internal and external motivation for school-age children is one of the important factors arising children's interest in education. External motivation can lead to internal motivational stimuli. Therefore the motivation of parents is needed to stimulate the growth of children's interest. With the emergence of needs arises also the desire for someone to fulfill them or realize them in various forms. Motivation is forms that exist in the brain human, which functions as a driving force to do something to meet their needs. ${ }^{18}$

Motivation is essentially the basic capital in achieving educational success, so that children truly realize the importance of education to achieve their future goals. Because motivation is a motor for learning.

According to the acknowledgment of the santri graduates of the salaf Islamic Boarding School, they stated that we have never received direction from parents to pursue higher education. The parents only directed us to continue to the Islamic Boarding School, because the Islamic Boarding School can print their students to get good religious knowledge. (Interview results, 08/08/2018).

The data indicate that, the motivation of parents to pursue higher education height was not felt by the santri. This means that the

${ }^{18}$ S. Hardjono, Prinsip-Prinsip Pengajaran Bahasa dan Sastra (Jakarta:

Departatemen Pendidikan dan Kebudayaan,1988), 74. 
low level of santri's education as a result of the absence of a touch of encouragement from parents. This also means that parents' motivation is one factor in the low education of santri. The low level of santri education can lead to an increase in unemployment for graduates of the salaf Islamic Boarding School. The data above is supported by the following quantitative data:

\begin{tabular}{llcc}
\hline No & Parental Encouragement & Amount & Percentage \\
\hline 1. & Never & 26 & $26 \%$ \\
2. & Never & 74 & $74 \%$ \\
\hline & & $100 \%$ & $100 \%$ \\
\hline
\end{tabular}

The data show $74 \%$ of santri stated that they never received encouragement from parents, and only $26 \%$ who stated that they were encouraged by parents to continue their education to a higher level. This means that most of them did not continue to higher education, so as an alternative they continued their education to the salaf Islamic Boarding School. This also means that the low level of santri's education is also due to the lack of motivation of parents. Thus it can be said that the quantitative data also supports that qualitative data that, the encouragement of parents is also one of the factors in the number of unemployed graduates of the salaf Islamic Boarding School.

\section{Parental Economic Factors}

The economic well-being of a household greatly determines the sustainability of the education of their children. The level of economic prosperity of parents of Islamic Boarding Schools is actually included in the economic group that is sufficient. Based on direct observation in the field, the economic condition of parents is quite good. It can be seen from the homes and household appliances that are owned by the majority including well-off people. However, to continue his sons and daughters to a higher level is felt by parents. Likewise the results of the interviews show their statement as follows:

If the economic problem is thank God, the meaning for the family's daily needs and to send the children in the hut is not so difficult, all of Allah guarantees. But to continue their education 
the child is still a little scared because of the high cost. (Interview results, 12/08/2018)

The data indicates that the parents of the Salaf Islamic Boarding School are still at the level of continuing their children's education to the Islamic Boarding School. In general, they feel reluctant to continue their education to their children in public schools, for fear that the costs will be high and they will be afraid of being unable. The data is supported by the following quantitative data:

\begin{tabular}{|c|c|c|c|}
\hline No & Economic Level of Parents & Number of & Percentages \\
\hline 1. & Rich & 11 & $11 \%$ \\
\hline 2. & Less rich & 43 & $43 \%$ \\
\hline 3. & Poor & 46 & $46 \%$ \\
\hline & Total & 100 & $100 \%$ The \\
\hline
\end{tabular}

The Data show $11 \%$ of parents graduating from salaf Islamic Boarding School including category capable, $43 \%$ less capable, and $46 \%$ unable. The data confirms that most parents graduating from the Salaf Islamic Boarding School are categorized as poor. Therefore, they feel reluctant and afraid to continue their children's education to a higher level of education. The low level of education of a person can make it difficult to get a decent job. This means that the family's economic well-being is also a factor in the many unemployed graduates of the Salaf Islamic Boarding Schools.

\section{Discussion}

\section{Islamic Boarding Schools Between Tradition, Culture, and Self- forging}

The term santri comes from the word sastri which comes from the Sansekerta language which means teachings or instruction. Islamic Boaarding Schools in general are born and developed because of the support of rural communities, both communities around Islamic Boarding Schools and the wider community, depending on their needs 
for Islamic Boarding School and the role of Islamic Boarding School for the community. ${ }^{19}$

Thus, the word Islamic Boarding School can be defined as a place of learning for students who are nuanced in Islamic religion. Whereas the meaning of the message of salaf here is the Islamic Boarding School which focuses its study only on religious sciences (diniyah) which are managed traditionally with paternalistic culture which is still maintained. Paternalistic culture is the obedience of santri (students) to kyai (teacher) who have crystallized and become tarekat (way) in daily life habits that are consistently and continuously practiced both during the Islamic Boarding School and after returning to the midst of people's lives. The emergence of the Islamic Boarding School was initially a fortress of community power when it was suppressed by tyrannical rulers, such as Sunan Giri Prapen who appeared to guide the people in facing the Mataram Kingdom in collusion with the VOC, Kyai Maja who appeared to accompany Prince against the Dutch colonizers. ${ }^{20}$

The world of Islamic Boarding School is a world where most of its contents are related to the problems of conventions and traditions involving traditional Muslim communities, most of which live in rural areas. Islamic boarding schools are known as institutions that have their own culture, namely the culture of the Islamic Boarding School community that reflects the distinctive culture of traditional rural communities. Huts and dormitories are the components that make santri become independent human beings because in these places they learn religion and then teach and produce religious books or other religious nuances. ${ }^{21}$

The relationship between santri and kyai is very close. Obedience of santri to kyai is a tradition that has been crystallized and

\footnotetext{
19 A. Sutarto, Pesantren dan Politik Tinjauan Kultural-Historis dalam Menguak Pergumulan antara Seni, Politik, Islam, dan Indonesia (Jember: Kompyawisda \& Jember University, 2004).

20 "Karomah Sunan Prapen Pelantik Raja-raja Islam di Nusantara," July 29, 2017, https://daerah.sindonews.com/read/1225040/29/karomah-sunan-prapen-pelantik-rajaraja-islam-di-nusantara-1501256091

${ }^{21}$ A. Sutarto, Pesantren, Budaya Lokal, dan Prahara Informasi dalam menjinakkan globalisasi: Tentang Peran Strategis Produk-Produk Budaya Lokal (Jember: Kompyawisda \& Universitas Jember, 2002).
} 
has become a tarekat, namely daily life habits that are carried out consistently and continuously. Kyai is a figure who becomes the foundation of questions, consultation and all kinds of complaints concerning religious and community issues. Kyai is a source of information about obedience, a figure that is always used as a reference or reference in the life of Islamic Boarding School. ${ }^{22}$

Admittedly or not, nowadays the world of Islamic Boarding School has changed that it needs observing, especially those concerning the lives of kyai and santri and those related to their functions and roles. Change has taken place very far and fast. Islamic Boarding Schools are no longer busy with routine studies of the kitab kuning (yellow book), but they use it as an inspirational source for modernizing rural life. Islamic Boarding Schools are not just a place to study religion traditionally, but also become a base for doing things related to the interests of society more broadly, for example the development of non-governmental organizations. ${ }^{23}$ Thus, it can be said that Islamic boarding schools are now religious education institutions that not only teach religious knowledge to their students, but Islamic boarding schools also play a role in community empowerment. ${ }^{24}$

Life in Islamic Boarding Schools strives to instill a soul of mutual help (ta'awanu), a simple lifestyle, giving birth to a steel minded character 'test resistant', resilient to environmental conditions, and can also foster awareness of independent living. Calling the head of Islamic Boarding School with the word 'kloraan' is a recognition of the existence of leaders in the Islamic Boarding School community. $\mathrm{He}$ is not just kyai's confidant to guide and supervise the respected and admired santri. The highest leader in an Islamic Boarding School is an authoritative Kyai, who regulates not only because of power, but also because of the inner relationship between the leader (kyai) and the one led (santri). Kyai's charisma is not onle based on a decree, but also

\footnotetext{
${ }^{22}$ F.M. Manshur, "Budaya Pesantren dan Tradisi Pengajian Kitab," Humaniora, no. 8 (1998): 46-52.

23 A. Wahid, Pergulatan Negara, Agama, dan Kebudayaan (Depok: Desantara, 2001).

${ }^{24}$ M. Hasan, "Wasatiyyah Islam in The Pesantren Islamic Education Tradition Framework," KARSA 26, no. 2 (2018): 177-194.
} 
because of its nature and character. ${ }^{25}$ The charisma of the Kyai is also inseparable from the hereditary charisma, which means that the charisma is revealed by its predecessors. When a wife of Kyai (Nyai) gives birth to a child, then the child bears the title immediately, if he is a man, he is called "gus/lora" while if he is a woman "neng/nyai".

\section{Various Types of Islamic Boarding Schools}

The types of education in various Islamic boarding schools are in accordance with the goals and developments that occur both in the Islamic Boarding School world and in the community. There are several types of Islamic Boarding School based on their teaching patterns, namely: (1) Shari'at type is Islamic Boarding Schools that focus more on the teaching of religious sciences that have Islamic nuances, such as interpretation, hadith, fiqh, mustholah hadith, etc. ; (2) Type of language is an Islamic Boarding School which focuses more on teaching Arabic, including nahwu sharaf, insya', balaghah as a tool to facilitate understanding the Sharia sciences which are standard in Arabic books; (3) Tariqat type is a Islamic Boarding School that follows certain tariqot streams which have gradually spread widely in Indonesia; (4) Type of agriculture and carpentry: in this Islamic Boarding School after the recitation of the yellow books, santri are trained in farming and carpentry skills. However, this type of Islamic boarding schools is rarely applied in salaf Islamic Boarding Schools; (5) Type of psychotherapy is a Islamic Boarding School that seeks to cure public health problems that cannot be cured medically, meaning that the Islamic Boarding School specifically has the goal of healing and rehabilitation of people who have psychiatric problems; (6) The type of applied technology is similar to the type of agriculture and carpentry - outside of school hours students are trained in the skills of motorcycle, radio, television, sewing, welding and so on; (7) type of Tahfidzul Qur'an is Islamic Boarding School that is oriented towards memorizing the Koran; (8) Mixed type is Islamic Boarding School that combines several types; (9) Type of students, namely the type of Islamic Boarding School which is mostly santri from various public universities and various disciplines; (10) The type of farm laborer is a boarding school which some of the students do not get the living

${ }^{25}$ Ibid. 
expenses from their families. They are determined while studying to make a living as laborers from the community around the Islamic boarding school, as workers in the fields, fields, yards, etc .; (11) The type of factory employee is a boarding school that is almost similar to a farm laborer, they recite while making a living in a factory located around the Islamic boarding schools. ${ }^{26}$

\section{The Importance of Entrepreneurship in Islamic Boarding Schools}

The term entrepreneurship comes from the word entrepreneur (French) which is translated into English with the meaning between taker or go between. Many terms about entrepreneurship is more universal and accumulates other opinions that entrepreneurship is a process of creating something different by devoting all of its time and energy accompanied by financial, psychological, social risks and receiving remuneration in the form of money and personal satisfaction. ${ }^{27} 28$

This understanding is reinforced by the opinion Hall \& Lenox (2010) that entrepreneurship is a person who breaks down the existing economic system by introducing new goods and services by creating new forms of organization or processing new raw materials. The person conducts his activities through an existing business organization. Entrepreneurs are the person who perceives opportunity and creates an organization to pursue it. ${ }^{29}$

In this definition, it is emphasized that an entrepreneur is a person who sees opportunities to create an organization to take advantage of these opportunities. Entrepreneurship here emphasizes everyone who starts a new business whereas the entrepreneurial

\footnotetext{
${ }^{26}$ Ibid.

${ }^{27}$ R.D. Hisrich, M. P. Peters, "Entrepreneurship: Starting, developing, and managing a new enterprise" Homewood, IL: Irwin. Google Scholar, (1995).

28 G. T. Lumpkin and G.G. Dess, "Clarifying the Entrepreneurial Orientation Construct and Linking It To Performance," Academy of Management Review 21, no.1 (1996), https://journals.aom.org/doi/pdf/ 10.5465/amr.1996.9602161568

${ }^{29}$ J. Hall, J. Daneke \& M. Lenox, "Sustainable development and entrepreneurship: past contributions and future directions," Journal of Business Venturing 25, (2010): 439-448.
} 
process includes all the functions and actions to pursue and take advantage of opportunities by creating an organization.

An entrepreneur is not always a trader (businessman) or a manager; he (entrepreneur) is a unique person who carries risk takers and introduces innovative products and new technologies into the economy. Only a few entrepreneurs can look forward and innovative who can feel the potential of new invention in using it. After the introduction of successful innovations from the entrepreneur, other entrepreneurs followed suit and the new products or technologies spread in economic life. There are three standard traits that exist in every human being, namely: thirst for power (need of power), thirst for gathering (need of affiliation), and the need for achievement (need of achievement). To move the product so that achievement in development, what needs to be encouraged is all the elements that can support the need of achievement that has now been found. All the elements that support the need of achievement are not possible to learn from the west, but we should try to explore ourselves from all the meaningful and high-value cultural elements found in the treasury of each tribe in our own homeland. The philosophy of life that are like mental viruses found in various regions in Indonesia must be inventoried, then the elements that advance us are fueled nationally and the elements that prevent us from leaving.

In terms of entrepreneurial behavior, three types of entrepreneurs can be classified as follows: (1) Entrepreneurs who have initiatives; (2) entrepreneurs who organize social and economic mechanics to produce something; (3) who can be at risk or accept failure. For economists an entrepreneur is a person who combines resources, labor, materials and other equipment to increase values higher than before, and also people who introduce changes, innovations, and improvements to other production. In other words, entrepreneurship is a person or group of people who organize factors of production, nature, energy, capital, and skills for the purpose of producing both goods and services. For a psychologist, an entrepreneur is a person who has the power to push from within to obtain a goal, likes to conduct experiments or to display his freedom outside the power of others. For a businessman or entrepreneur it is a threat, a new competitor or can be a partner, supplier, consumer or someone who can be invited to work together. For a financier see 
entrepreneurship is someone who creates prosperity for himself and others, who find new ways to use resources, reduce waste, and open employment opportunities favored by the community.

Entrepreneurship is the process of dynamics to create additional prosperity. This added prosperity was created by entrepreneurial individuals who bear the risk, spend time, and provide a variety of goods and services. The goods and services produced may not be new items but must have new and useful values by utilizing existing skills and resources. In the sense of entrepreneurship the concepts are summed up like new situations, organizing, creating, prosperity and risk handling. Entrepreneurship is found in all professions such as education, health, research, law, architecture, engineering, social work and distribution.

Entrepreneurship is the process of creating something is the process of creating something else by using time and activities along with capital and risk and receiving reward and satisfaction and personal freedom. ${ }^{30}$ Provide a definition of entrepreneurship by emphasizing the aspects of business freedom which are stated as follows that the entrepreneur is an independent, growth-oriented owner operator.

Many forms of freedom arise from this definition. One form of freedom is corporate entrepreneurs, or entrepreneurs who are usually not owners of the company but they run the company as well as the owner. Therefore, Raymond Kao sees a range of spectrum from this aspect of freedom. The range of freedom moves from a purely free individual entrepreneur to a manager in a company owned by someone else.

Based on the description above the term entrepreneur has different meanings for everyone because they see this concept from various perspectives. However, there are some general aspects contained in the meaning of entrepreneurs, namely the existence of several general aspects contained in the notion of entrepreneurship, namely the existence of elements of risk, creativity, efficiency, freedom, and reward.

\footnotetext{
${ }^{30}$ Ibid.
} 
Future entrepreneurial growth in our country is very bright. We face the future, namely the development period of entrepreneurial activities supported by educational institutions that develop entrepreneurial knowledge driven also by government policies and various assistances from private companies. Therefore, it is very important in salaf Islamic Boarding School, where the students do not have sufficient formal education to provide skills and management that leads to the formation of Islamic Boarding School who are devoted and have sufficient skills to meet their future. Thus Islamic Boarding School graduates no longer add to the number of unemployed people, but can even create work.

\section{Conclusion}

The entrepreneurship behavior of Salaf Islamic Boarding School graduates is seen from the type of work they occupy, the type of skills they have, the ability to do entrepreneurship, after graduating from a Salaf Islamic Boarding School that it can be categorized as very low. It was found out several factors that caused the unemployment rate of Salaf Islamic Boarding School graduates, namely cultural factors which only focused on the study of yellow books, the factors of santri's education which were classified as very low, Islamic Boarding School curriculum factors that did not lead to entrepreneurship, parents' low education factors, economic factors parents who influence the sustainability of their children's education. Among these factors, the pattern of teaching factors in the Islamic Boarding School are considered to be the most dominant santri because there is no curriculum that can provide entrepreneurial skills for santri.

\section{Acknowledgement}

I would like to express my deepest appreciation to Rector of University of Jember who has provided this research group grant to produce an out put of this scientific article. Furthermore, I would also like to acknowledge with much appreciation the Dean of Faculty of Cultural Science, and Head of Magister of Linguistics Department, who have me given support so that the research implementation of this article can run smoothly.

\section{Bibliography}


Alma, B. Entrepreneurship: For Students and the Public. Bandung: Alfabeta, 2008.

Bogdan, R. and I.S. Taylor. Introduction to Qualitative Research to the Social Sciences. New York: John \& Sons Inc., 1975.

Hall, J. J. Daneke and M. Lenox. "Sustainable development and entrepreneurship: past contributions and future directions." Journal of Business Venturing 25, (2010): 439-448.

Halim, W. "Peran Pesantren dalam Wacana dan Pemberdayaan Masyarakat Madani." Akademika 22, no. 02 (2017): 191-218.

Hamid, A. Pendidikan Karakter Berbasis Pesantren: Pelajar dan Santri dalam era IT dan Cyber Culture. Surabaya: Imtiyas, 2017.

Haryono, A. Etnografi Komunikasi: Konsep, Teori, dan Contoh Penelitian Pola Komunikasi. Jember: UPT Publishing University of Jember, 2015.

Haryono, A. "Pola Komunikasi di Pesantren Salaf 'A' Jember (Kajian Sosiolinguistik).” Master's thesis, Universitas Negeri Surabaya, 2006.

Haryanto, S. "Persepsi Santri Terhadap Perilaku Kepemimpinan Kiai di Pondok Pesantren: Studi Interaksionisme Simbolik di Pondok Pesantren Sidogiri Pasuruan.” PhD thesis, Universitas Islam Negeri Maulana Malik Ibrahim, 2011.

Hardjono, S. Prinsip-Prinsip Pengajaran Bahasa dan Sastra. Jakarta: Departatemen Pendidikan dan Kebudayaan, 1988.

Hasan, M. "Wasatiyyah Islam in The Pesantren Islamic Education Tradition Framework." KARSA 26, no. 2 (2018):177-194.

Himmah, R.H., and M.A. Amrulloh. "Pengembangan Kurikulum Bahasa Arab Pesantren Mu'adalah (Studi Kasus di Pondok Pesantren Al-Kausar Genteng Banyuwangi)." Jurnal Al Bayan 9, no. 2 (2017): 75-89.

Hisrich, R.D. and M.P. Peters. Entrepreneurship: Starting, Developing, and Managing a New Enterprise. Homewood, IL: Irwin, 1995.

Isbahi, M. B. "Budaya "Pakewuh" Santri pada Kyai:Relevansi Budaya Pendidikan Pesantren terhadap Tantangan Dunia 
Islam di Era Globalisasi" Millatī, Journal of Islamic Studies and Humanities 3, no.1 (2018): 103-124.

Izfanna, D. and N.A. Hisyam. "A comprehensive approach in developing akhlaq: A case study on the implementation of character education at Pondok Pesantren Darunnajah." Multicultural Education \& Technology Journal 6, no. 2 (2012): 77-86. doi:10.1108/17504971211236254

Kompri. Manajemen \& Kepemimpinan Pondok Pesantren. Jakarta: Prenadamedia Group (Divisi Kencana), 2018.

Lumpkin, G. T. and G.G. Dess. "Clarifying the Entrepreneurial Orientation Construct and Linking It to Performance." Academy of Management Review 21, no.1 (1996). https:// journals.aom.org/doi/pdf/10.5465/amr.1996.9602161568.

Mastuhu. Dinamika Sistem Pendidikan Pesantren: Suatu Kajian Tentang Unsur Dan Nilai Sistem Pendidikan Pesantren. Jakarta: INIS, 1994.

Manshur, F.M. "Budaya Pesantren dan Tradisi Pengajian Kitab." Humaniora, no. 8 (1998): 46-52.

Maunah, B. "Pesantren in the Perspective Social Change." Jurnal Ushuluddin 30, (2009): 251-282.

Moleong, J. Lexy. Metode Penelitian Kualitatif. Bandung: PT. Remaja Rosdakarya, 1993.

Nasir. A. S. "Pendidikan Islam di Pesantren (Studi tentang Tipe Pesantren)." Jurnal Pancaran Pendidikan 16, no.4 (2003): 96106.

Rahardjo, Dawam (ed.). Pesantren dan Pembaharuan. Jakarta: LP3ES, 1988.

Raihani, "Exploring Islamic School Leadership in a Challenging Southern Thailand Context." Studia Islamika: Indonesian Journal for Islamic Studies 24, no.2 (2017): 271-294.

Sari, M.M.E. "The Role of Learning Management of Islamic Boarding School (Pesantren) in Improvement of Their Students Religious Tolerance in West Java Indonesia." International Journal of Innovation and Applied Studies 19, no.1 (2017): 2432.

Sutarto, A. Pesantren, Budaya Lokal, dan Prahara Informasi dalam Menjinakkan Globalisasi: Tentang Peran Strategis Produk- 
Produk Budaya Lokal. Jember: Kompyawisda \& Universitas Jember, 2002.

Sutarto, A. Pesantren dan Politik Tinjauan Kultural-Historis dalam Menguak Pergumulan antara Seni, Politik, Islam, dan Indonesia. Jember: Kompyawisda \& Universitas Jember, 2004.

Wahid, A. Pergulatan Negara, Agama, dan Kebudayaan. Depok: Desantara, 2001.

Wardi, M. "Pengembangan entrepreneurship berbasis experiential learning di pesantren Al-Amien Prenduan Sumenep dan Darul Ulum Banyuanyar Pamekasan." PhD Thesis, UIN Sunan Ampel Surabaya, 2017. 